\title{
CHANGES IN PUBLIC PERCEPTIONS OF RIVER BASIN MANAGEMENT PRIORITY ISSUES OVER THE LAST 28 YEARS IN THE PACIFIC NORTHWEST, USA
}

\author{
ROBERT L. MAHLER ${ }^{1} \&$ MICHAEL ERNEST BARBER ${ }^{2}$ \\ ${ }^{1}$ Soil Science Division, University of Idaho, USA \\ ${ }^{2}$ Department of Civil and Environmental Engineering, University of Utah, USA
}

\begin{abstract}
Residents of the Pacific Northwest region of the USA have considered water issues their highest environmental resource priority for over 50 years. We surveyed the public living in the Columbia basin watershed in the states of Idaho, Washington and Oregon about the water issues they considered most important in 1988, 1994, 2002, 2007, 2012 and 2016. Each of these six mail-based surveys was unique; however, all surveys contained three identical questions so that changes in public opinions and priorities over time could be measured. Demographic information about survey respondent gender, age, community size and formal education level were also collected. The public opinion changes observed over this 28 -year period were significant. The opinions that were constant regardless of time were: (1) most people considered water in the Columbia basin to be of good or better quality, (2) most residents considered the Columbia basin to provide adequate quantities of water, (3) and over $60 \%$ of the public found that power generation was the most important benefit provided by waters of the Columbia-Snake River System. Overall, the public living in the Columbia-Snake River Watershed is engaged and care about water issues. This engagement is becoming increasingly important as more interests compete for the limited supplies of water in the region.
\end{abstract}

Keywords: public concerns, public opinion, Columbia river basin, water quality, water quantity.

\section{INTRODUCTION}

The Columbia-Snake River Watershed (CSRW) has a large economic impact in both Canada and the USA. This system is key to the economies of British Columbia, Washington, Idaho, Oregon and Montana as it supports agriculture (5,000,000 irrigated ha), commerce, power production, direct human water consumption, food processing and recreation. Previously conducted surveys have shown than that the public within the region consider water their most important natural resource and that there are significant concerns about both water quality and water quantity issues within this large river basin [1]-[4].

\section{BACKGROUND}

The Columbia-Snake River Watershed produces over $50 \%$ of the water flow to the Pacific Ocean from the contiguous portion of the western USA. Over $60 \%$ of the USA's hydropower production capacity is found in this watershed. The large amounts of water within this basin have resulted in the development of large tracts of irrigated farmland that produce over 100 commodities each valued at more than $\$ 5,000,000$.

The public in the Pacific Northwest has a high awareness level of the watershed benefits. Much of the water flowing through the watersheds rivers originates as snowpack in the Cascade and Rocky Mountains during the late fall, winter and early spring. Over 40 major dams capture the runoff water in reservoirs. Consequently, this water provides hydroelectric power in the spring and summer months, provides enough water to irrigate over 5,000,000 ha of farmland, serves as a major transportation artery because of locks present at most dams, and provides many recreational activities for the region's population. Even though river basin planning and management has occurred in most regions of the world over the last 85 years, 
results have often been disappointing [5]. Today the emphasis on river basin management is an integrated approach [6]. The concept of river basin and river basin management has changed significantly over time [7]. For instance, international river basin treaties have largely focused on water use and water quantity issues; however, water quality aspects have become much more important in recent years [8]. Many integrated approaches have incorporated scenarios that address climate change [9]-[11]. It is important that the public have input in river basin management. Their perceptions on pollutants, water quality, water quantity, fisheries, health of riparian vegetation, local and national governance, and the effectiveness of existing programs to make river basin management satisfactory and sustainable is important [11]-[13].

The purpose of this paper is to document changes about public perceptions of water quantity and water quality within the Columbia-Snake River Watershed (CSRW) over a 28year period. Public input has also been sought on a regular basis (1988, 1994, 2002, 2007, 2012 and 2016) to identify the major benefit of the Columbia-Snake River Watershed. A map of the Columbia-Snake River System is shown in Fig. 1.

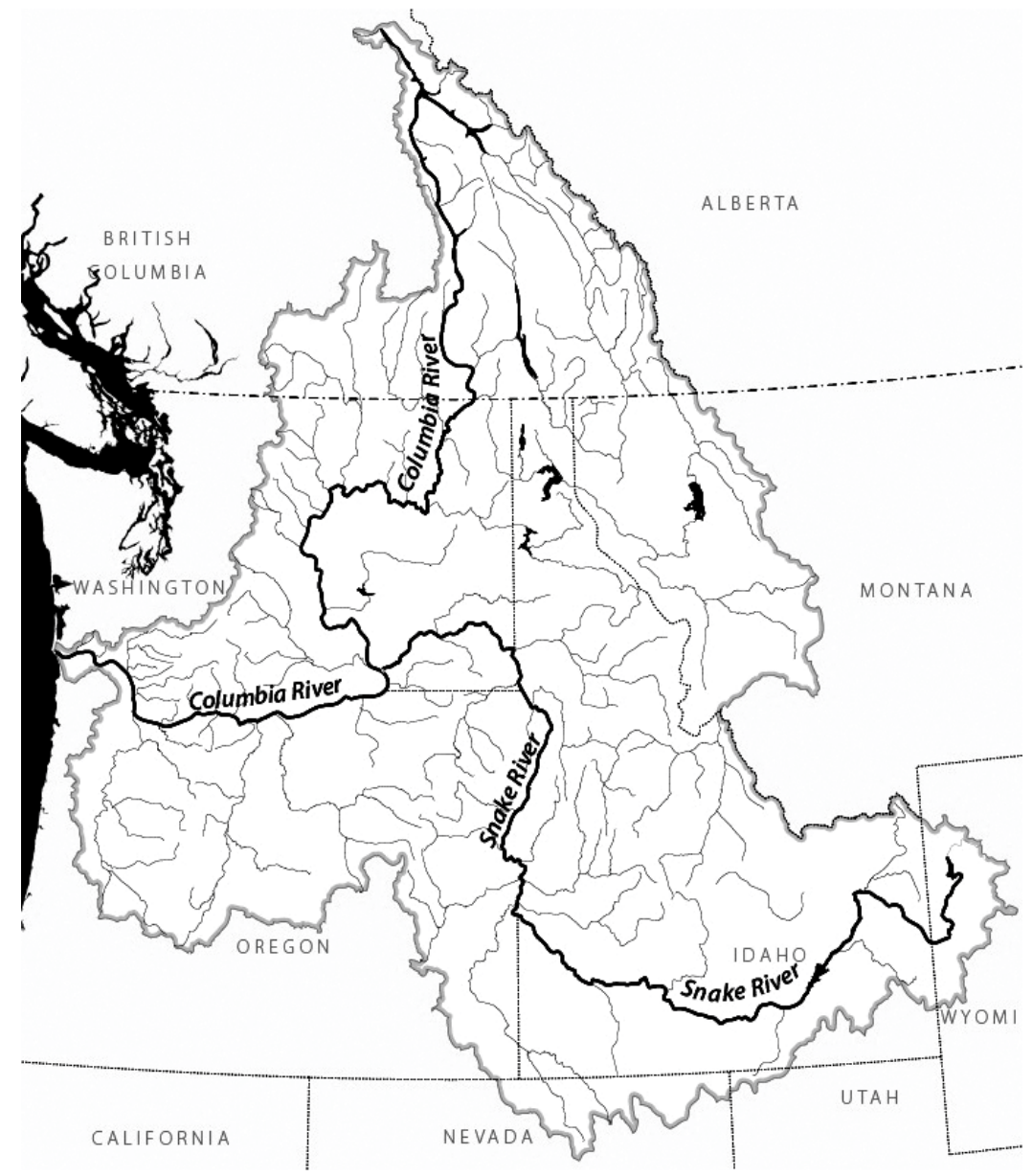

Figure 1: Map of the Columbia-Snake River Basin.(Courtesy of the Columbia River InterTribal Fish Commission, Portland, OR, USA.) 


\section{METHODOLOGY}

Survey instruments containing between 24 and 40 questions were developed to access public attitudes, priorities and concerns about water resource issues, river management and the potential impacts of climate change in the Pacific Northwest in 1988, 1994, 2002, 2007, 2012 and 2016. All six surveys contained the three following questions which are the topic of this paper:

- In your opinion what is the quality of surface water where you live? Answer choices: excellent or good, fair, poor, no opinion/I don't know;

- In your opinion is the quantity of surface water enough to meet human needs? Answer choices: more than adequate, adequate, less than adequate, much less than adequate, no opinion/I don't know;

- In your opinion what is the most important benefit provided by the Columbia-Snake river system? Answer choices: biodiversity, drinking water, fisheries, food/agriculture, power generation, recreation, transportation/commerce.

The survey target audience was a representative sample of the 9,000,000 adult residents of Idaho, Oregon and Washington that live within the CSRW or highly dependent on its waters. In addition, demographic information, including state of residence, community size, length of time residing in the region, gender, age, and educational level were also collected from survey respondents.

In each survey year, a target of 1,000 completed questionnaires was chosen as the survey goal to result in a sampling error of 4-6\% [14]. The survey process was designed to receive a completed survey return rate more than $50 \%$. Addresses were obtained from a professional social sciences survey company (SSI, Norwich, CT). Four mailings were planned to achieve the $50 \%$ return rate [15], [16]. The mailing strategy used was identical in all six surveys that had been conducted in the region since 1970 [1]-[4].

It only took three mailings to achieve the target return rate of 50\% in 2002, 2007, 2012 and 2016. Conversely it took four mailing to achieve the 50\% return rate in 1988 and 1994. The first mailing included the water issues survey form, a business reply envelope, and a cover letter that: (1) identified the survey's authors; (2) explained the purpose of the survey; (3) assured the respondent of anonymity; and (4) asked the respondents to fill out and return the survey via the business reply envelope. The second mailing (four weeks later) consisted of a postcard that stressed the importance of the survey and remind the respondent to fill out and return the survey sent out in the first mailing. Five weeks later the third mailing was sent to residents who did not respond to the first or second mailing. This mailing included a reminder letter, another copy of the water issues survey, and a business reply envelope. The fourth mailing, used in 1988 and 1994 consisted of a reminder postcard six weeks after the third mailing.

Survey answers were coded and entered into Microsoft Excel. Missing data were excluded from the analysis. The data were analyzed at two levels using SAS [16]. The first level of analysis generated frequencies, while the second level evaluated the impacts of demographic factors. Significance $(\mathrm{P}<0.05)$ to demographic factors was tested using a chi-square distribution [14]-[16]. Since similar response rates were observed in all six survey years, data analysis procedures were identical for each sampling.

\section{RESULTS AND DISCUSSION}

The survey methodology used in the study was not designed to be unique, but rather to be used as a tool to ascertain useful information. The survey methodology was designed to 
access public attitudes and concerns about Columbia River Basin water quality, quantity and its priority human benefit over a 28 -year time-period.

All six survey years achieved a survey return rate more than 50\%. Fifty-one percent of the survey respondents were male. Over $40 \%$ of survey respondents lived in communities of more than 100,000 people. Conversely, $18 \%$ of respondents lived in towns with less than 7,000 people. Almost half of the survey respondents attended at least one year of college. The demographics of the survey respondents mirrored the 1990, 2000 and 2010 USA census data. Thus, the survey respondents were representative of the actual population living in the Pacific Northwest. Consequently, when coupled with the low sampling error of the survey, respondents can be equated to residents in the following discussion.

4.1 Water quality within the Columbia-Snake System

All survey residents of Idaho, Oregon and Washington were asked their opinion of surface water quality within the CSRW regardless of where they lived in the region (inside or outside of this watershed). In general, over $40 \%$ of respondents considered water quality to be good or excellent (Table 1). Conversely, between 9.1 and $22.2 \%$ considered surface water quality poor depending on survey year. Approximately $10 \%$ of the respondents had no opinion on the quality of surface water.

Table 1: Public views about the quality of surface waters (rivers) in the Columbia-Snake River System based on 1988, 1994, 2002, 2007, 2012 and 2016 surveys.

\begin{tabular}{|l|l|l|l|l|l|l|}
\hline Water quality & 1988 & 1996 & 2002 & 2007 & 2012 & 2016 \\
\hline & \multicolumn{5}{|l|}{$\%$} \\
\hline Excellent/good & 46.2 & 44.2 & 47.0 & 50.1 & 55.3 & 58.3 \\
\hline Fair & 21.4 & 24.2 & 20.1 & 18.6 & 19.7 & 20.3 \\
\hline Poor & 20.4 & 22.2 & 21.6 & 15.7 & 10.3 & 9.1 \\
\hline No opinion & 12.0 & 9.4 & 11.3 & 15.6 & 14.7 & 12.3 \\
\hline
\end{tabular}

Table 2: The influence of the demographic factors of gender, time, age and education level on public views about the quality of surface waters (rivers) in the Columbia-Snake River System based on 1988, 1994, 2002, 2007, 2012 and 2016 surveys.

\begin{tabular}{|c|c|c|c|}
\hline Demographic factor & Parameter & Good/excellent (\%) & Significance \\
\hline \multirow[t]{2}{*}{ Gender } & Female & 40.0 & \multirow{2}{*}{$* * *$} \\
\hline & Male & 60.2 & \\
\hline \multirow[t]{3}{*}{ Time } & 1988 & 46.2 & \multirow{3}{*}{$* *$} \\
\hline & 2002 & 47.0 & \\
\hline & 2016 & 58.3 & \\
\hline \multirow[t]{3}{*}{ Age } & $<30$ years & 37.6 & \multirow{3}{*}{$* * *$} \\
\hline & $30-60$ years & 53.1 & \\
\hline & $>60$ years & 62.1 & \\
\hline \multirow[t]{3}{*}{ Education } & $<$ HS diploma & 64.2 & \multirow{3}{*}{$* *$} \\
\hline & HS diploma & 49.2 & \\
\hline & College & 50.3 & \\
\hline
\end{tabular}


The demographic factors of gender, survey year, age and formal education level impacted how people viewed surface water quality in the watershed (Table 2). Males were twice as likely as females to give surface water quality a good or excellent quality rating. Water quality ratings changed over time - with quality ratings improving over this 28 -year study period. 2016 survey respondents were significantly more likely to give surface water quality ratings of good or excellent (58.3\%) than survey takers in 1988, 1996 and 2002. This 28-year change resulted in going from a majority of the public rating water quality from less than good to excellent in 1988 to a majority giving scores of good to excellent in 2016.

The age of survey respondent also impacted views on surface water quality (Table 2). Respondents younger than 30 years were less likely to give good or excellent water quality scores than older respondents. Respondents older than 60 years were most likely than other age groups to give good or excellent ratings. Formal education level also impacted views toward surface water quality. Respondents with high school diplomas or some college education were less likely to view surface water quality favorably that respondents who had not received high school diplomas.

\subsection{Water Quantity within the Columbia-Snake System}

Based on surveys conducted in the region between 1988 and 2016 at least $66 \%$ of the residents believed that the quantity of surface water in the CSRW was adequate or more than adequate (Table 3). Conversely, less than $25 \%$ of residents considered the quantity of surface water to be much less than adequate. The demographic factors of gender, survey year, age and education impacted how people viewed the water quantity issue in the region (Table 4). Males were more likely than females ( 79 vs. $66 \%$ ) to consider the quantity of water in the system to be adequate or more than adequate.

Differences as a consequence of survey year were also significant. Survey respondents were more likely to consider water resources adequate in 1988 and 2002 than in 2016 (Table 4). The water needs within the region have grown since 1988 and people today are more likely to consider the water resources as not unlimited. The majority of the public still thinks that there are plenty of water resources within the region in 2016, but this number is substantially lower than the view just nine years ago.

Younger survey respondents ( $<30$ years) were less likely to consider the region's water resources adequate than those in the 30-60 and >60-year age groups (Table 4). Many of the younger people surveyed were taught the importance of water conservation in schools and thus are more realistic about the region's limited water resources. Survey respondents with a college education were less likely to consider the amount of water resources adequate than people with less years of formal education (Table 4).

Table 3: Public views about the quantity of surface waters (rivers) in the Columbia-Snake River System based on 1988, 1994, 2002, 2007, 2012 and 2016 surveys.

\begin{tabular}{|c|c|c|c|c|c|c|c|}
\hline Water quality & 1988 & 1996 & 2002 & 2007 & 2012 & 2016 \\
\hline & \multicolumn{7}{|c|}{$\%$} \\
\hline More than adequate & 60 & 58 & 57 & 52 & 53 & 49 \\
\hline Adequate & 20 & 20 & 18 & 20 & 16 & 17 \\
\hline Less than adequate & 7 & 7 & 9 & 9 & 13 & 18 \\
\hline Much less than adequate & 2 & 2 & 4 & 3 & 5 & 6 \\
\hline No opinion & 11 & 13 & 12 & 16 & 15 & 10 \\
\hline
\end{tabular}


Table 4: The influence of the demographic factors of gender, time, age and education level on public views about the quantity of surface waters (rivers) in the Columbia-Snake River System based on 1988, 1994, 2002, 2007, 2012 and 2016 surveys.

\begin{tabular}{|c|c|c|c|}
\hline Demographic factor & Parameter & Good/excellent (\%) & Significance \\
\hline \multirow[t]{2}{*}{ Gender } & Female & 66 & \multirow{2}{*}{$* * *$} \\
\hline & Male & 79 & \\
\hline \multirow[t]{3}{*}{ Time } & 1988 & 80 & \multirow{3}{*}{$* * *$} \\
\hline & 2002 & 75 & \\
\hline & 2016 & 63 & \\
\hline \multirow[t]{3}{*}{ Age } & $<30$ years & 49 & \multirow{3}{*}{$* *$} \\
\hline & $30-60$ years & 72 & \\
\hline & $>60$ years & 86 & \\
\hline \multirow{3}{*}{ Education } & $<$ HS diploma & 86 & \multirow{3}{*}{$* * *$} \\
\hline & HS diploma & 80 & \\
\hline & College & 56 & \\
\hline
\end{tabular}

Table 5: Local perception of the most important benefit of the Columbia-Snake River System based on 1988, 1994, 2002, 2007, 2012 and 2016 surveys.

\begin{tabular}{|l|l|l|l|l|l|l|}
\hline $\begin{array}{l}\text { Most } \\
\text { important } \\
\text { benefit }\end{array}$ & 1988 & 1994 & 2002 & 2007 & 2012 & 2016 \\
\hline & \multicolumn{6}{|c|}{$\%$} \\
\hline $\begin{array}{l}\text { Power } \\
\text { production }\end{array}$ & 59 & 60 & 62 & 58 & 56 & 53 \\
\hline $\begin{array}{l}\text { Food/ } \\
\text { agriculture }\end{array}$ & 17 & 20 & 16 & 19 & 20 & 23 \\
\hline Recreation & 15 & 13 & 14 & 15 & 16 & 16 \\
\hline $\begin{array}{l}\text { Transport/ } \\
\text { commerce }\end{array}$ & 15 & 13 & 14 & 15 & 16 & 16 \\
\hline $\begin{array}{l}\text { Drinking } \\
\text { water }\end{array}$ & 6 & 3 & 4 & 5 & 6 & 2 \\
\hline Fisheries & 1 & 2 & 2 & 1 & 1 & 1 \\
\hline Biodiversity & 1 & 0 & 0 & 0 & 0 & 1 \\
\hline
\end{tabular}

\subsection{Most important benefit of the Columbia-Snake Watershed}

Over $50 \%$ of the respondents living in the CSRW cited power production as the main benefit of the system (Table 5). Watershed residents also often identified food/agriculture (from 16 to $23 \%$ ) and recreation (from 13 to $16 \%$ ) as the main benefit of the large watershed. Far fewer watershed residents listed transportation, drinking water, fisheries and biodiversity as the most important benefit provided by the river system.

Well over $60 \%$ of respondents living outside the CSRW, but within Idaho, Oregon and Washington identified power production as the most important benefit of the river system (Table 6). These residents also often identified drinking water (from 9 to $16 \%$ ) and recreation 
(from 11 to 16\%) as the main benefit of the CSRW. Far fewer Idaho, Oregon and Washington residents living outside this watershed identified food/agriculture, fisheries, biodiversity and transportation/commerce as the most important benefit of this large watershed.

When people living in the CSRW were compared to people in Idaho, Oregon and Washington living outside the watershed differences about the most important benefit of the were observed (Table 7). First, people living outside the watershed were more likely to identify power generation as the most important benefit of the watershed (64 vs. 58\%). Second, respondents outside the watershed were also more likely to identify drinking water s arce (13 vs. $4 \%$ ) as the most important benefit of the Columbia-Snake watershed. Conversely, residents of the Columbia-Snake watershed were more likely than nonwatershed residents (19 vs. $5 \%$ ) to identify food/agriculture as the most important watershed benefit.

When people living in the CSRW were compared to people in Idaho, Oregon and Washington living outside the watershed differences about the most important benefit of the were observed (Table 7). First, people living outside the watershed were more likely to identify power generation as the most important benefit of the watershed (64 vs. 58\%). Second, respondents outside the watershed were also more likely to identify drinking water s arce (13 vs. $4 \%$ ) as the most important benefit of the Columbia-Snake watershed. Conversely, residents of the Columbia-Snake watershed were more likely than nonwatershed residents (19 vs. $5 \%$ ) to identify food/agriculture as the most important watershed benefit.

Table 6: Perceptions of people living in the Pacific Northwest - but outside the ColumbiaSnake River Watershed of the most important benefit of the Columbia-Snake River System based on 1988, 1994, 2002, 2007, 2012 and 2016 surveys.

\begin{tabular}{|l|l|l|l|l|l|l|l|}
\hline Most important benefit & 1988 & 1994 & 2002 & 2007 & 2012 & 2016 \\
\hline & \multicolumn{6}{|c|}{$\%$ \% } \\
\hline Power production & 62 & 62 & 63 & 66 & 66 & 64 \\
\hline Drinking water & 9 & 10 & 16 & 14 & 15 & 16 \\
\hline Recreation & 16 & 14 & 14 & 12 & 11 & 12 \\
\hline Food/agriculture & 6 & 8 & 5 & 6 & 2 & 4 \\
\hline Fisheries & 3 & 4 & 2 & 2 & 0 & 0 \\
\hline Biodiversity & 2 & 1 & 0 & 0 & 1 & 2 \\
\hline Fisheries & 3 & 4 & 2 & 2 & 0 & 0 \\
\hline Transport/commerce & 1 & 1 & 0 & 0 & 1 & 0 \\
\hline
\end{tabular}

Table 7: Comparing survey respondents inside and outside the Columbia-Snake River Watershed on their view of the most important benefit provided by the watershed. Data from all six survey years are combined (1988, 1994, 2002, 2007 , 2012 and 2016).

\begin{tabular}{|l|l|l|l|}
\hline \multirow{2}{*}{ Most important benefit } & \multicolumn{2}{|c|}{ Comparing } & \multirow{2}{*}{ Significance } \\
\cline { 2 - 4 } & Inside CSRW & Outside CSRW & \\
\hline & \multicolumn{2}{|c|}{ \% citing as most important } \\
\hline Power generation & 58 & 64 & $* *$ \\
\hline Recreation & 15 & 13 & NS \\
\hline Drinking water & 4 & 13 & $* * *$ \\
\hline Food/agriculture & 19 & 5 & $* * *$ \\
\hline Transport/commerce & 2 & 0.5 & $* *$ \\
\hline Fisheries & 1 & 3 & $*$ \\
\hline Biodiversity & $<0.1$ & 1 & $* *$ \\
\hline
\end{tabular}


People in and outside the Columbia-Snake river watershed saw the benefit of recreation similarly. Although the numbers were low residents of the CSRW were more likely than nonresidents to say that transportation/commerce was the number one benefit of the watershed. Conversely, residents of the Pacific Northwest living outside the Columbia-Snake river watershed were more likely to say that fisheries ( 3 vs. $1 \%$ ) and biodiversity ( 1 vs. $0.1 \%$ were the most important benefit of the large watershed system.

The next major comparison was between urban people living within the Columbia-Snake River Watershed with urban people in Idaho, Oregon and Washington residing outside the watershed. In this comparison, a person was identified as an urban resident if they lived in a community of more than 20,000 people. The urban public living outside the Columbia-Snake watershed were more likely to cite power generation (64 vs. 58\%) and drinking water (16 vs. $2 \%$ ) than their urban counterparts living within the watershed (data not shown).

When survey respondents living inside the CSRW are divided into urban and rural residents, three interesting observations can be made (Table 8). First, urban residents in the watershed are more likely to identify power generation ( 58 vs. $47 \%$ ) as the most important benefit of the river system. Second, rural residents were more likely to identify food/agriculture (26 vs. 18\%) or recreation (18 vs. 14\%) as the most important benefit provided by the watershed. Third, urban and rural residents viewed drinking water, transportation/commerce, fisheries and biodiversity low, but similarly as to their likelihood to be the most important benefit of the Columbia-Snake river system.

Although most people in the western USA view the CSRW as primarily rural in character, there are over 49 cities in this watershed with more than 20,000 residents. This includes 11 cities in Idaho, 12 cities in Washington and 26 cities in Oregon. In fact, the watershed's urban population is more than five times larger than the rural population (people living in places with less than 20,000 people). Although urban residents dominate the watershed, their views on the value of benefits provided by the overall watershed are in-line with their rural counterparts. For instance, urban residents of the watershed see the importance of food/agriculture to a much greater extent than Pacific Northwest urban resident living outside the watershed boundaries.

\section{CONCLUSIONS AND RECOMMENDATIONS}

Residents of Idaho, Oregon and Washington appreciate quality and quantity of water provided by the Columbia-Snake River Watershed. This water source has both direct and

Table 8: Comparing answer of urban and rural survey respondents living in the Columbia-Snake River Watershed on their view of the most important benefit provided by the watershed. Data from all six survey years are combined (1988, 1994, 2002, 2007, 2012 and 2016).

\begin{tabular}{|c|c|c|c|}
\hline \multirow[t]{2}{*}{ Most important benefit } & \multicolumn{2}{|c|}{ Comparing } & \multirow[t]{2}{*}{ Significance } \\
\hline & Urban residents & Rural residents & \\
\hline & \multicolumn{3}{|c|}{$\%$ citing as most important } \\
\hline Power generation & 58 & 47 & $* *$ \\
\hline Recreation & 14 & 18 & $*$ \\
\hline Drinking water & 2 & 2 & NS \\
\hline Food/agriculture & 18 & 26 & $* *$ \\
\hline Transport/commerce & 4 & 5 & NS \\
\hline Fisheries & 2 & 1 & NS \\
\hline Biodiversity & 2 & 1 & NS \\
\hline
\end{tabular}


indirect positive impacts on all residents of this region. One of the most important findings of this set of six surveys conducted over a 28 -year period is the consistency of public answers about water quantity, water quality and the important benefits of this river system. Key findings of this study include:

- The perception of water quality in the Columbia-Snake River System improved over the 28 -year study period. Over $58 \%$ of the public rated water quality as good or excellent in 2016 compared to $48 \%$ in 1988 .

- Most survey respondents considered water quantity in the region adequate or more than adequate in all six survey years; however, this percentage has slipped from $80 \%$ in 1988 to $66 \%$ in 2016 .

- Men were more likely to say that water quality was good or excellent and that water quantity was adequate or more than adequate than women.

- Survey respondents older than 60 years were more likely to give water quality and water quantity higher grades than respondents younger than 30 years.

- College educated respondents were more concerned about water quantity issues in the Columbia-Snake watershed than people with less formal education.

- Surveys conducted over this 28-year period showed that most people in Idaho, Oregon and Washington consider power production to be the main benefit provided by the Columbia-Snake River Watershed.

- Respondents living outside the Columbia-Snake River Watershed have consistently seen drinking water and recreation as important benefits of the watershed, while watershed residents view food/agriculture and recreation as the second and third most important benefits of the system.

\section{REFERENCES}

[1] Mahler, R.L., Simmons, R., Sorensen, F. \& Miner, J.R., Priority water issues in the Pacific Northwest. Journal of Extension, 42(5), Article 5RIB3, 2004, Online. http://www.joe.org/joe/2004october/rb3.php.

[2] Mahler, R.L., Gamroth, M., Pearson, P., Sorenson, F., Barber, M.E. \& Simmons, R., Information sources, learning opportunities and priority water issues in the Pacific Northwest. Journal of Extension, 48(2), Article 2RIB2, 2010, Online. http://www.joe.org/joe/2010april/rb2.php.

[3] Mahler, R.L., Simmons, R. \& Sorensen, F., Drinking water issues in the Pacific Northwest. Journal of Extension, 43(6), Article 6RIB6, 2005, Online. http://www.joe.org/joe/2005december/rb6.php.

[4] Mahler, R.L. \& Barber, M.E., Rivers and river basin management issues and concerns in the Pacific Northwest, USA. WIT Transactions on Ecology and the Environment, 197, 2015. ISSN 1743-3541. doi: 10.2495/RM150011.

[5] Barrow, C.J., River basin development planning and management: a critical review. World Development, 26(1), pp. 171-186, 1998.

[6] Downs, P.W., Gregory, K.J. \& Brookes, A., How integrated is river basin management? Environmental management, 15(3), pp. 299-309, 1991.

[7] Molle, F., River-basin planning and management: the social life of a concept. Geoforum, 40, pp. 484-494, 2009.

[8] Shmueli, D.F., Water quality in international river basins. Political Geography, 18, pp. 437-476, 1999.

[9] Cohen, S.J., Miller, K.A., Hamlet, A.F. \& Avis, W., Climate change and resource management in the Columbia River basin. Water International, 25, pp. 253-272, 2000. 
[10] Payne, J.T., Wood, A.W. \& Hamlet, A. F., Mitigating the effect of climate change on water resources of the Columbia River basin. Climate Change, 62, pp. 233-256, 2004.

[11] Palmer, M.A. et al., Climate change and the world's river basins: anticipating management options. Frontiers in Ecology and the Environment, 6(2), pp. 81-89, 2008.

[12] Huang, S., Huang, Q., Chang, J. \& Leng, G., Linkages between hydrological drought, climate indices and human activities: a case study in the Columbia River basin. International Journal of Climatology, 36(1), pp. 280-290, 2016.

[13] Edwards, M.L., Public perceptions of the legitimacy of water governance organizations in Nebraska and Washington. Society and Natural Resources, 29(3), pp. 265-283, 2016.

[14] Salent, P. \& Dillman, D., How to Conduct your Own Survey, John Wiley and Sons, Inc. New York, New York, 1994.

[15] Dillman, D., Mail and Internet Surveys: The Tailored Design Method, John Wiley and Sons, Inc.: New York, New York, 2000.

[16] SAS Institute Inc., SAS Online Document 9.1.3, SAS Institute Inc. Cary: North Carolina, 2004. 